\title{
MULTIPLE DISEASE RESISTANCE IN DOGWOODS (CORNUS SPP.) TO FOLIAR PATHOGENS
}

\author{
by M.T. Mmbaga ${ }^{1}$ and R.J. Sauvé ${ }^{2}$
}

Abstract. Disease resistance in several Cornus species and cultivars to three foliar pathogens was evaluated in a 5-year study. Of the 51 accessions evaluated, 20 were of $C$. kousa, 21 of $C$. florida, two of $C$. sericea, two of $C$. mas, one of $C$. alternifolia, and five were interspecific hybrids of $C$. kousa $\times C$. florida. Powdery mildew and spot anthracnose caused by Erysiphe (sect. M icrosphaera) pulchra, and Elsinoe corni, respectively, were the most prevalent and severe diseases. Eighteen cultivars of $C$. kousa, one of $C$. mas, two of $C$. sericea, one of $C$. alternifolia, and four interspecific hybrids were highly resistant to powdery mildew, while $19 \mathrm{C}$. florida cultivars were susceptible, of which two were moderately resistant. Spot anthracnose was the second most prevalent disease, but its severity was generally low. Three $C$. kousa cultivars, ten of $C$. florida, and one of $C$. mas were mildly susceptible to spot anthracnose. Both cultivars of C. sericea were highly susceptible to Septoria leaf spot (Septoria cornicola), and heavy infections were observed throughout the study. Most C. florida cultivars were highly susceptible to powdery mildew, while most $\mathrm{C}$. kousa cultivars were highly resistant. Results of this study suggest that multiple disease resistance in dogwoods may be achieved through crosses between $\mathrm{C}$. kousa and $\mathrm{C}$. florida.

Key W ords. Powdery mildew; Erysiphe (sect. M icrosphaera) pulchra; Septoria leaf spot; Septoria cornicola; spot anthracnose; Elsinoe corni; Cornus alternifolia; C. florida; C. mas; C. sericea; C. kousa; $\mathrm{C}$. kousa $\times \mathrm{C}$. florida; host resistance.

The flowering dogwood (Cornus florida L.) and the kousa dogwood (C. kousa Hans.) are popular ornamental trees in the United States. Powdery mildew is the most important disease that affects flowering dogwood production in U.S. southeastern states (Hagan et al. 1995; McRitchie 1994; Ranney et al. 1994; M mbaga 1998, 2000). Plants in full sun and shade are affected by powdery mildew, and the disease persists throughout the season.

Previously, powdery mildew was thought to have no effect on landscape plantings, but recent studies have shown that this disease stunts growth (M mbaga 1998) and reduces the number of flower buds set (H artman 1998). Severe infections have al so been associated with plant death in seedlings (Daughtrey and Hagan 2001). In nursery production, infections with powdery mildew reduce the market value of plants and also increase the time needed for plants to reach prime size for marketing. To reduce losses caused by this disease, fungicide applications have become a routine practice in commercial nurseries. For effective control, fungicide applications begin at budbreak and continue throughout the growing season (W heeler 1978; M mbaga and Sheng 2002), resulting in increased production costs and reduced profit. Environmental concerns have also been raised concerning the effects of fungicides on nontarget organisms and on the potential contamination of ground and surface water.

Dogwood species and cultivars have different levels of susceptibility to powdery mildew. Most C. kousa cultivars are highly resistant, while most $\mathrm{C}$. florida are susceptible (Ranney et al. 1994; Hagan et al. 1995, 1997; W indham 1996; M mbaga et al. 2001). 'Cherokee Brave', a C. florida cultivar, has been reported to have a high level of resistance (Ranney et al. 1994; Hagan et al. 1995). However, its resistance to mildew has not held in some locations in the United States, and its susceptibility to other common diseases has not been reported.

Two fungi, Phyllactinia guttata (syn. P. corylea) and Erysiphe (sect. M icrosphaera) pulchra (syn. M. pulchra) have been associated with powdery mildew (Braun and Takamatsu 2000; M mbaga 2000, 2002). However, their distribution and degree of virulence are not known. In middle Tennessee, $E$. pulchra is the dominant pathogen; $P$. guttata is rarely found (M mbaga 2000). The spore-producing bodies of powdery mildew, cleistothecia, play a significant role in winter survival and are a source of primary inoculum in the spring (M mbaga 2000, 2002). Because cleistothecia are formed as the result of sexual conjugation, new genetic strains of the fungus continue to develop (M mbaga 2000, 2002). Thus, commercial cultivars need to be continually monitored for powdery mildew susceptibility.

In Tennessee, spot anthracnose caused by Elsinoe corni occurs throughout the growing season. Although the disease is not usually severe, it significantly reduces the aesthetic value of infected plants. This disease causes carbohydrate depletion via early defoliation and plant stunting, which sometimes results in death of young seedlings (Daughtrey and Hagan 2001). Another disease that affects dogwood is a leaf blight caused by Septoria cornicola. Because severe infections usually occur late in the growing season, this disease is not of much concern (Sinclair et al. 1987; Daughtrey and Hagan 2001). The avoidance of dogwood cultivars susceptible to multiple diseases would reduce grower production costs and environmental contamination with fungicides. 
Dogwood anthracnose caused by Discula destructiva is a disease of great concern throughout most eastern areas of the United States. This disease is often severe in locations such as natural forests, in high-density nursery production systems, and in shaded landscape plantings. However, dogwood anthracnose was not observed in this study because our evaluation plots were located in a sunny, welldrained area, an environment not highly favorable for this disease (Sinclair et al. 1987; Daughtrey and Hagan 2001).

The objectives of this study were to evaluate popular commercial dogwood cultivars for resistance to foliage diseases that occur frequently in middle Tennessee and to identify multiple disease-resistant clones for use in our breeding program.

\section{MATERIALS AND METHODS}

Plant Material

A total of 51 cultivars of five different species (C. alternifolia, C. florida, C. mas, C. sericea, C. kousa) and of C. kousa $\times$ C. florida interspecific crosses were obtained from commercial nurseries. Field plots were established at Tennessee State University, Nursery Crop Research Center in McM innville, Tennessee. Plants were either bare root or balled and burlapped $(B \& B)$ and ranged in size from 1.22 to $1.83 \mathrm{~m} \mathrm{(4}$ to $6 \mathrm{ft}$ ). Trees were established during December 1996 and

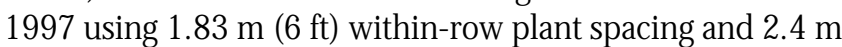
( $8 \mathrm{ft}$ ) between-row spacing. The experiment was conducted and analyzed as a randomized complete block design with five replicates for each cultivar. Plants were maintained in the field following Bailey and Brown's guide for growing dogwoods (Bailey and Brown 1991). Trees were fertilized with a controlled-release fertilizer (14-14-14) at the beginning of May and drip irrigated as needed. Tree trunks were sprayed with chlorpyrifos (Dursban ${ }^{\circledR}$ ) during June or early July (based on insect trapping data) of every growing season to control wood-boring insects.

Disease Development and Evaluation

Beginning with the 1999 season, C. florida plants in $40 \mathrm{~L}$ (10 gal) containers maintained in a shade house were inoculated with E. pulchra by scattering crushed leaf debris containing mature cleistothecia. After infection and after the last frost date, these plants- referred to as disease spreaders- were placed between test plants using the pot-in-pot system. Disease spreaders were used to provide a source of primary inoculum early in the season and to enhance uniform inoculum availability within the evaluation plot area. In the previous seasons, trees were naturally infected resulting in nonuniform infection.

The development of powdery mildew was monitored at regular intervals and disease severity was rated monthly beginning in June and ending during late August or early September. The disease rating scale used was as follows: $0=$ no infection, $1=1 \%$ to $10 \%, 2=11 \%$ to $25 \%, 3=26 \%$ to
$50 \%, 4=51 \%$ to $75 \%$, and $5=76 \%$ to $100 \%$ of foliage area with disease symptoms. The highest numerical ratings observed were during the months of August and early September. These data were used to assess the relative susceptibility of each cultivar in the study. The overall performance of each cultivar over the 5-year study was determined by averaging the highest disease readings over the 5-year period. The cultivars were categorized resistant (R) when mean disease readings were between 0.0 and 1.0, moderately resistant (MR) between 1.1 and 2.0, moderately susceptible (MS) between 2.1 and 2.9, and susceptible (S) between 3.0 and 5.0. Spot anthracnose and Septoria leaf spot resulting from natural infection were evaluated at the same time as powdery mildew using the same rating system.

Data Analysis

Data analysis was performed using the SAS (Statistical Analysis Systems, Inc., Cary, NC) general linear models procedure (Schlotzauer and Littell 1987). Multiple comparisons of the mean disease severities from treatments were conducted using a series of t-tests between pairs of means following SAS procedures in PROC ANOVA and PROC GLM.

\section{RESULTS}

Early powdery mildew symptoms and signs of the causal agent were first observed in the first week of June in 1998 and 2001 and the first week of May in 1999, 2000, and 2002. Disease severity increased over time; the highest disease ratings were recorded in late summer during the last week of August in 1998, 2000, and 2001 and first week of September 1999. Disease severity varied from year to year, with the highest severity recorded in 2002 , followed by 2000 (Tables 1 and 2) and the lowest during 1999. Low powdery mildew incidence in 1999 was attributed to the unusually hot and dry conditions during July and August 1999 (data not shown). The use of spreader plants as sources of inoculum improved disease uniformity within cultivars as compared to results obtained from the 1998 evaluation when they were not used.

M ost cultivars of C. kousa, C. mas, C. sericea, and C. alternifolia were highly resistant to powdery mildew (Table 1). Two cultivars of C. kousa, 'Bush Pink' and 'Spring Grove', were moderately susceptible (Table 2). Of the $21 \mathrm{C}$. florida cultivars, 19 were highly susceptible and two showed some resistance to powdery mildew. They were 'Fragrant Cloud' and 'Cherokee Brave' (Table 1). Four of the five interspecific hybrids of $\mathrm{C}$. florida $\times \mathrm{C}$. kousa were resistant to powdery mildew ('Celestial', 'Stellar Pink', 'Constellation', and 'Aurora'); 'Ruth Ellen' was slightly susceptible (Table 1).

The second most prevalent disease evaluated was spot anthracnose. This disease occurred annually beginning in early June and peaked during July or August. However, disease severity was generally moderate except in a few cultivars (Table 3). During the 1999 growing season, 
Table 1. Cornus cultivars resistant to powdery mildew under field conditions 1998-2001.

\begin{tabular}{|c|c|c|c|c|c|c|c|}
\hline \multirow{2}{*}{ Cornus species } & \multirow[b]{2}{*}{ Cultivar } & \multicolumn{5}{|c|}{ Mean powdery mildew severity ${ }^{z}$} & \multirow[b]{2}{*}{ Mean } \\
\hline & & 1998 & 1999 & 2000 & 2001 & 2002 & \\
\hline C. kousa & Agate & $0 \mathrm{j}$ & $0 \mathrm{j}$ & $0 \mathrm{j}$ & 01 & $0.0 \mathrm{~h}$ & 0 \\
\hline C. kousa & Autumn Rose & $0 \mathrm{i}$ & $0 \mathrm{j}$ & $0 \mathrm{j}$ & 01 & $0.0 \mathrm{~h}$ & 0 \\
\hline C. kousa & Big Apple & $0 \mathrm{i}$ & $0 \mathrm{j}$ & $0 \mathrm{j}$ & 01 & $0.0 \mathrm{~h}$ & 0 \\
\hline C. kousa & Blue Shadow & $0 \mathrm{i}$ & $0 \mathrm{j}$ & $0 j$ & 01 & $0.0 \mathrm{~h}$ & 0 \\
\hline C. kousa & China Girl & $0 \mathrm{i}$ & $0 \mathrm{j}$ & $0 \mathrm{j}$ & 01 & $0.0 \mathrm{~h}$ & 0 \\
\hline C. kousa & var. chinensis & $0 \mathrm{i}$ & $0 \mathrm{j}$ & $0 \mathrm{j}$ & 01 & $0.0 \mathrm{~h}$ & 0 \\
\hline C. kousa & Dwarf Pink & $0 \mathrm{i}$ & $0 \mathrm{j}$ & $0 \mathrm{j}$ & 01 & $0.0 \mathrm{~h}$ & 0 \\
\hline C. kousa & Emerald Star & $0 \mathrm{i}$ & $0 \mathrm{j}$ & $0 j$ & 01 & $0.0 \mathrm{~h}$ & 0 \\
\hline C. kousa & Gold Star & $0 \mathrm{i}$ & $0 \mathrm{j}$ & $0 \mathrm{j}$ & 01 & $0.0 \mathrm{~h}$ & 0 \\
\hline C. kousa & Lustgarten Weeping & $0 \mathrm{i}$ & $0 \mathrm{j}$ & $0 \mathrm{j}$ & 01 & $0.0 \mathrm{~h}$ & 0 \\
\hline C. kousa & Moonbeam & $0 \mathrm{i}$ & $0 \mathrm{j}$ & $0 \mathrm{j}$ & 01 & $0.0 \mathrm{~h}$ & 0 \\
\hline C. kousa & Satomi & $0 \mathrm{i}$ & $0 \mathrm{j}$ & $0 j$ & 01 & $0.0 \mathrm{~h}$ & 0 \\
\hline C. kousa & Square Dance & $0 \mathrm{i}$ & $0 \mathrm{j}$ & $0 \mathrm{j}$ & 01 & $0.0 \mathrm{~h}$ & 0 \\
\hline C. kousa & Wolf Eyes & $0 \mathrm{i}$ & $0 \mathrm{j}$ & $0 \mathrm{j}$ & 01 & $0.0 \mathrm{~h}$ & 0 \\
\hline C. sericea & Cardinal & $0 \mathrm{i}$ & $0 \mathrm{j}$ & $0 \mathrm{j}$ & 01 & $0.0 \mathrm{~h}$ & 0 \\
\hline C. sericea & Isante & $0 \mathrm{i}$ & $0 \mathrm{j}$ & $0 j$ & 01 & $0.0 \mathrm{~h}$ & 0 \\
\hline C. mas & Redstone & $0 \mathrm{i}$ & $0 \mathrm{j}$ & $0 \mathrm{j}$ & 01 & $0.0 \mathrm{~h}$ & 0 \\
\hline C. mas & Golden Glory & $0 \mathrm{i}$ & $0 \mathrm{j}$ & $0 \mathrm{j}$ & 01 & $0.0 \mathrm{~h}$ & 0 \\
\hline C. alternifolia & Pagoda & $0 \mathrm{i}$ & $0 \mathrm{j}$ & $0 \mathrm{j}$ & 01 & $0.0 \mathrm{~h}$ & 0 \\
\hline C. kousa & Trinity Star & $0 \mathrm{i}$ & $0 \mathrm{i}$ & -- & -- & $0.0 \mathrm{~h}$ & 0 \\
\hline C. kousa & Japanese Cornel & $0 \mathrm{i}$ & $0 \mathrm{i}$ & -- & -- & $0.0 \mathrm{~h}$ & 0 \\
\hline C. kousa & Milky Way & $0.7 \mathrm{hi}$ & $0.5 \mathrm{hij}$ & $0 \mathrm{j}$ & 01 & $0.2 \mathrm{~h}$ & 0. \\
\hline C. kousa & Snow Flake & $0.3 \mathrm{i}$ & $0.6 \mathrm{hij}$ & $0 \mathrm{j}$ & 01 & $0.0 \mathrm{~h}$ & 0.2 \\
\hline C. kousa $\times$ C. florida & Stellar Pink & $0.0 \mathrm{i}$ & $0.3 \mathrm{i}$ & $0.1 \mathrm{j}$ & $0.3 \mathrm{kl}$ & $0.5 \mathrm{~h}$ & 0.2 \\
\hline C. kousa $\times$ C. florida & Celestial & $0.7 \mathrm{hi}$ & $0.5 \mathrm{hij}$ & $0.1 \mathrm{j}$ & $0.3 \mathrm{kl}$ & $0.3 \mathrm{~h}$ & 0.4 \\
\hline C. kousa $\times$ C. florida & Constellation & $1.0 \mathrm{hi}$ & $0.5 \mathrm{hij}$ & $0.5 \mathrm{j}$ & $0.5 \mathrm{jkl}$ & $0.5 \mathrm{~h}$ & 0.6 \\
\hline C. kousa $\times$ C. florida & Aurora & $1.0 \mathrm{hi}$ & $1.0 \mathrm{fghij}$ & $0.5 \mathrm{j}$ & $0.8 \mathrm{jkl}$ & -- & 0.8 \\
\hline C. florida & Fragrant Cloud & $1.0 \mathrm{hi}$ & $0.4 \mathrm{ij}$ & $2.5 \mathrm{ghi}$ & $1.5 \mathrm{fgh}$ & 3.0 def & 1.4 \\
\hline C. kousa $\times$ C. florida & Ruth Ellen & $1.0 \mathrm{hi}$ & $1.0 \mathrm{fghi}$ & $2.4 i$ & 2.5 cde & $0.5 \mathrm{~h}$ & 1.7 \\
\hline \multirow[t]{2}{*}{ C. florida } & Cherokee Brave & $2.3 \mathrm{ef}$ & $0.5 \mathrm{hij}$ & $2.1 \mathrm{ef}$ & $2.9 \mathrm{~cd}$ & $1.8 \mathrm{~g}$ & 1.9 \\
\hline & $\operatorname{LSD}_{(0.05)}$ & 1.1 & 1.1 & 0.9 & 0.8 & 1.1 & \\
\hline
\end{tabular}

2Disease severity readings $1=1 \%$ to $10 \%, 2=11 \%$ to $25 \%, 3=26 \%$ to $50 \%, 4=51 \%$ to $75 \%$, and $5=76 \%$ to $100 \%$ plant infection.

yStatistical differences between cultivars are presented across Tables 1-2. Numbers followed by same letters in the same column are statistically similar at $\mathrm{P}=0.05$ according to t-tests between pairs of means calculated by Statistical Analysis Systems (SAS).

infection was mild because of unfavorable environmental conditions and was highest during 2001 and 2002 (Table 3). Cultivars with morethan $10 \%$ of foliage showing disease symptoms are presented in Table 3; cultivars that developed insignificant disease levels are not shown. Cultivars of C. kousa that were most susceptible to spot anthracnose were 'Lustgarten Weeping', 'Satomi', and 'Wolf Eyes'. Cornusmas 'Golden Glory', C. florida 'Cherokee Sunset', C. florida 'Little Princess', and C. florida 'Rainbow' were also very susceptible (Table 3 ).

Septoria leaf spot was insignificant on all cultivars except on two red-osier (C. sericea) cultivars ('Cardinal' and 'Isante') that were severely infected (Table 3). Characteristic angular lesions of Septoria leaf spot began in May, and by the end of June, more than $50 \%$ of leaves and young twigs were infected. Severe defoliation occurred, and stem lesions that girdled young twigs caused dieback every year. By mid-July,
$75 \%$ of plants' foliage had developed brown necrotic lesions covering most of the foliage. The aesthetic appearance of the plants was severely impacted.

\section{DISCUSSION}

Dogwood cultivars evaluated in this study are commonly available at most nurseries that specialize in the production of dogwood. Annual variations in climatic conditions during the 5-year study contributed to seasonal variations in disease severity. Hot, dry weather has been associated with low disease incidence, and moderate temperatures with evenly distributed rainfall have been associated with high powdery mildew severity (Aust and Hoyningen-Huene 1986; M mbaga 2002). The hot, dry weather during July and August 1999 may be responsible for low disease incidence recorded during that season. 
Table 2. Cornus cultivars susceptible to powdery mildew under field conditions 1998-2002.

\begin{tabular}{llllllll}
\hline & & \multicolumn{5}{c}{ Mean powdery mildew severity } \\
Cornus species & Cultivar & 1998 & 1999 & 2000 & 2001 & 2002 & Mean \\
\hline C. florida & Little Princess & $1.0 \mathrm{hi}$ & $0.4 \mathrm{ij}$ & $2.5 \mathrm{ghi}$ & $3.3 \mathrm{ab}$ & $3.0 \mathrm{def}$ & 2.0 \\
C. kousa & Bush Pink & $2.0 \mathrm{fgh}$ & $0.4 \mathrm{ij}$ & $2.9 \mathrm{efgh}$ & $2.6 \mathrm{cde}$ & -- & 2.0 \\
C. florida & World's Fair & $2.0 \mathrm{fgh}$ & $0.5 \mathrm{hij}$ & $2.6 \mathrm{fgh}$ & $2.5 \mathrm{cde}$ & $2.7 \mathrm{efg}$ & 2.1 \\
C. nutalli & Boyd & -- & $1.0 \mathrm{fghi}$ & $3.0 \mathrm{i}$ & $2.1 \mathrm{ef}$ & $2.5 \mathrm{fg}$ & 2.2 \\
C. kousa & Spring Grove & $1.7 \mathrm{fghi}$ & $0.5 \mathrm{hij}$ & $2.3 \mathrm{hi}$ & $2.5 \mathrm{cde}$ & $4.3 \mathrm{ab}$ & 2.3 \\
C. florida & Pink Beauty & $2.0 \mathrm{ef}$ & 2.5 & $2.5 \mathrm{cde}$ & $3.0 \mathrm{bc}$ & $2.5 \mathrm{efg}$ & 2.5 \\
C. florida & Pygmy & $1.7 \mathrm{gh}$ & 2.4 & $3.5 \mathrm{bcde}$ & $2.6 \mathrm{bcd}$ & $2.3 \mathrm{fg}$ & 2.5 \\
C. florida & Sterling silver & -- & 2.3 & $1.8 \mathrm{i}$ & $3.3 \mathrm{ab}$ & $2.8 \mathrm{ef}$ & 2.6 \\
C. florida & Plena & $1.0 \mathrm{hi}$ & 2.2 & $3.0 \mathrm{defgh}$ & $3.0 \mathrm{bc}$ & $4.0 \mathrm{ab}$ & 2.6 \\
C. florida & Red Beauty & $3.3 \mathrm{bcd}$ & 2.7 & $3.5 \mathrm{bcde}$ & $2.3 \mathrm{cde}$ & $2.3 \mathrm{fg}$ & 2.8 \\
C. florida & Cherokee & $3.0 \mathrm{bcd}$ & 2.5 & -- & -- & -- & 2.8 \\
C. florida & Barton & $2.3 \mathrm{def}$ & $2.3 \mathrm{bcd}$ & $2.4 \mathrm{hi}$ & $2.0 \mathrm{ef}$ & $5.0 \mathrm{a}$ & 2.8 \\
C. florida & Cherokee Chief & $3.3 \mathrm{bc}$ & 2.7 & $3.6 \mathrm{bcd}$ & $1.4 \mathrm{gh}$ & $3.8 \mathrm{abc}$ & 3.0 \\
C. florida & Cherokee Princess & $3.0 \mathrm{bcd}$ & 3.0 & $3.4 \mathrm{bcde}$ & $3.1 \mathrm{bc}$ & $2.7 \mathrm{efg}$ & 3.0 \\
C. florida & Wonderberry & $3.0 \mathrm{bcd}$ & 3.1 & $3.0 \mathrm{defh}$ & -- & -- & 3.0 \\
C. florida & Cloud 9 & $2.7 \mathrm{def}$ & 3.0 & $3.5 \mathrm{bcde}$ & $2.1 \mathrm{efg}$ & $4.5 \mathrm{a}$ & 3.2 \\
C. florida & Rainbow & $3.0 \mathrm{bcd}$ & 2.8 & $3.8 \mathrm{bcd}$ & $2.0 \mathrm{efg}$ & $4.3 \mathrm{ab}$ & 3.2 \\
C. florida & Rubra & $3.7 \mathrm{bc}$ & 3.3 & $2.9 \mathrm{abc}$ & $2.9 \mathrm{bcd}$ & $3.2 \mathrm{cde}$ & 3.2 \\
C. florida & Cherokee Sunset & $5.0 \mathrm{a}$ & $2.5 \mathrm{bcd}$ & $3.3 \mathrm{cdef}$ & $2.5 \mathrm{cde}$ & $4.0 \mathrm{ab}$ & 3.5 \\
C. florida & Ozark Spring & $2.3 \mathrm{ef}$ & $3.2 \mathrm{ab}$ & $4.6 \mathrm{a}$ & $3.5 \mathrm{ab}$ & $3.5 \mathrm{bcd}$ & 3.4 \\
C. florida & Purple Glory & $4.0 \mathrm{ab}$ & $3.6 \mathrm{a}$ & $4.0 \mathrm{abc}$ & $4.0 \mathrm{a}$ & $5.0 \mathrm{a}$ & 4.1 \\
& & & & & & & \\
& LSD & & & & & & \\
\end{tabular}

${ }^{2}$ Disease severity readings $1=1 \%$ to $10 \%, 2=11 \%$ to $25 \%, 3=26 \%$ to $50 \%, 4=51 \%$ to $75 \%$, and $5=76 \%$ to $100 \%$ plant infection. yStatistical differences between cultivars are presented across Tables 1-2. Numbers followed by same letters in the same column are statistically similar at $\mathrm{P}=0.05$ according to least significant differences calculated by Statistical Analysis Systems (SAS).

Only two cultivars of $\mathrm{C}$. florida- 'Fragrant Cloud' and 'Cherokee Brave' - were moderately resistant to powdery mildew (Table 1), and four cultivars C. florida- 'Little Princess', 'World's Fair', 'Pink Beauty', and 'Pygmy'- were moderately susceptible (Table 2). 'Fragrant Cloud' is susceptible in Alabama and North Carolina (Hagan et al. 1997) and 'Cherokee Brave' seems to have more consistent moderate resistance to powdery mildew (Ranney et al. 1994; Windham 1996; Hagan et al. 1995, 1997). Most C. kousa $\times$ C. florida interspecific hybrids evaluated were powdery mildew resistant. Similar results have been observed in Alabama (Hagan et al. 1995, 1997). However, in North Carolina, three C. kousa $\times$ C. florida hybrids ('Constellation', 'Ruth Ellen', and 'Star Dust') developed powdery mildew on more than $70 \%$ of their foliage (Ranney et al. 1994).

Differences in cultivar reactions to powdery mildew suggest that there is a need for a better understanding of the disease and of and host-pathogen relationships. Environmental factors and differences in degree of virulence within pathogenic species are likely sources of variations. Some researchers have reported that the interaction between environmental factors influencing powdery mildew pathogens and subsequent disease severity is complex. Temperatures, timing, and intensity of rainfall influence infection and disease severity (W heeler 1978; Aust and Hoyningen-Huene
1986). The presence of multiple pathogens in a specific location may also significantly contribute to differences in cultivar susceptibility. In N orth Carolina, two fungi ( $E$. pulchra and P. guttata) have been associated with powdery mildew in dogwoods (McRitchie 1994; Hagan and Mullen 1995). The effect of the combination of the two pathogens to disease severity is not known. In middle Tennessee, E. pulchra is the most commonly observed fungus and P. guttata is rarely found; thus, the latter is insignificant to the disease complex (M mbaga 2000, 2002, M mbaga and Sheng 2002). During this study, E. pulchra was the main powdery mildew pathogen.

Cultivars that were most resistant to powdery mildew, but highly susceptible to spot anthracnose and Septoria leaf spot, should not be grown where all three diseases occur. Four cultivars of $C$. kousa that were highly resistant to powdery mildew ('Lustgarten Weeping', 'Satomi', 'Wolf Eye', and 'Golden Glory') were susceptible to spot anthracnose, and the other 16 cultivars were resistant. Although the two red-osier cultivars ('Isanti' and 'Cardinal') were highly resistant to powdery mildew, they were highly susceptible to Septoria leaf spot (Tables 1 and 3). Septoria leaf spot is known to have little impact on dogwood growth or its aesthetic value (Daughtrey and Hagan 2001). However, results in this study showed that plant health and growth 
were severely impacted because of the severe dieback associated with this disease. Red-osier dogwoods are widely used in landscape plantings because their branches have attractive winter color. When red-osier dogwoods are planted in a landscape setting, protective fungicides to avoid this disease should be considered.

Powdery mildew and spot anthracnose cause annual losses in commercial nurseries throughout the southeastern states of the United States. Although C. kousa has high resistance to all three diseases, C. florida is still in high demand because of its impressive spring bloom. To reduce production costs and avoid dependency on the use of fungicides, dogwood cultivars with disease resistance should be chosen over the more susceptible ones. Results from this study suggest that interspecific hybrids between $\mathrm{C}$. kousa and $\mathrm{C}$. florida may have multiple disease resistance. Although $\mathrm{D}$. destructiva is known to be highly destructive on dogwood (Sinclair et al. 1987; Daughtrey and Hagan 2001), it was not observed in our well-drained, full-sun plots during the 5 -year study. However, this disease is commonly found in shaded, moist locations in Tennessee.

Information on diseases susceptibility in 51 commercial cultivars to three common foliar pathogens will facilitate informed decisions on the selection of cultivars that are less disease prone. The choice to grow cultivars that are prone to these common diseases necessitates considerations for fungicidal control measures.

\section{LITERATURE CITED}

Aust, H.J., and J. Hoyningen-Huene. 1986. Microclimate in relation to epidemics of powdery mildew. Ann. Rev. Phytopathology 24:491-510.

Braun, U., and S. Takamatsu. 2000. Phylogeny of Erysiphe, Microsphaera, U ncinula (Erysipheae) and Cystotheca, Podosphaera, Sphaerotheca (Cystotheceae) inferred from rDNA ITS sequences-Some taxonomic consequences. Schlechtendalia 4:1-33.

Bailey, K.R., and E.A. Brown, 1991. Growing and maintaining healthy dogwoods. USDA Forest Service Report R8-FR14.
Table 3. Cornus cultivars that showed different levels of susceptibility to spot anthracnose and Septoria leaf spot under field conditions 2001-2002.

\begin{tabular}{|c|c|c|c|c|c|}
\hline \multirow[b]{3}{*}{ Cornus species } & \multirow[b]{3}{*}{ Cultivar } & \multicolumn{4}{|c|}{ Mean disease severityz } \\
\hline & & \multicolumn{2}{|c|}{ Spot anthracnose } & \multicolumn{2}{|c|}{ Septoria leaf spot } \\
\hline & & 2001 & 2002 & 2001 & 2002 \\
\hline C. sericea & Cardinal & $0.00^{y}$ & 0.00 & $4.8 \mathrm{a}$ & $5.0 \mathrm{a}$ \\
\hline C. sericea & Isante & 0.00 & 0.00 & $4.9 \mathrm{a}$ & $4.6 \mathrm{a}$ \\
\hline C. kousa & Lustgarten Weeping & 1.5 fghij & $3.7 \mathrm{~b}$ & 0.00 & 0.00 \\
\hline C. kousa & Satomi & $2.8 \mathrm{~b}$ & $2.5 \mathrm{C}$ & 0.00 & 0.00 \\
\hline C. mas & Golden Glory & $2.8 \mathrm{bc}$ & $2.2 \mathrm{~cd}$ & 0.00 & 0.00 \\
\hline C. kousa & Wolf Eyes & $2.8 \mathrm{~b}$ & $2.3 \mathrm{C}$ & 0.00 & 0.00 \\
\hline C. florida & Cherokee Sunset & $2.5 \mathrm{bcd}$ & $2.3 c$ & 0.00 & 0.00 \\
\hline C. florida & Little Princess & 2.3 bcde & 1.3 def & 0.00 & 0.00 \\
\hline C. kousa & Dwarf Pink & 1.0 hijk Im & $3.3 \mathrm{~b}$ & 0.00 & 0.00 \\
\hline C. florida & Cherokee Chief & 1.4 fghijk & $2.0 \mathrm{~cd}$ & 0.00 & 0.00 \\
\hline C. florida & Rainbow & $2.6 \mathrm{bc}$ & $1.3 \mathrm{def}$ & 0.00 & 0.00 \\
\hline C. florida & Pink Beauty & 2.0 bcde & $1.3 \mathrm{def}$ & 0.00 & 0.00 \\
\hline C. kousa & Spring Grove & 1.8 defgh & $2.0 \mathrm{~cd}$ & 0.00 & 0.00 \\
\hline C. mas & Redstone & 1.4 fghijk & $2.2 \mathrm{~cd}$ & 0.00 & 0.00 \\
\hline C. florida & Cherokee Brave & 1.3ghijkl & 1.3 def & 0.00 & 0.00 \\
\hline C. florida & Rubra & $1.9 \mathrm{cdefg}$ & $0.7 \mathrm{efg}$ & 0.00 & 0.00 \\
\hline C. florida & Purple Glory & 1.8 defgh & 1.0 efg & 0.00 & 0.00 \\
\hline C. kousa & Emerald Star & 1.0 hijklm & 1.1 def & 0.00 & 0.00 \\
\hline C. florida & Sterling Silver & 1.6 efghi & $0.3 \mathrm{gh}$ & 0.00 & 0.00 \\
\hline C. florida & Red Beauty & 1.4 fghijk & $0.3 \mathrm{gh}$ & 0.00 & 0.00 \\
\hline C. kousa & Agate & 0.00 & $1.5 \mathrm{cde}$ & 0.00 & 0.00 \\
\hline C. kousa & China Girl & $0.4 \mathrm{mno}$ & 1.3 def & 0.00 & 0.00 \\
\hline $\operatorname{LSD}_{(0.05)}$ & & 0.8 & 0.8 & 0.8 & 0.8 \\
\hline
\end{tabular}

zDisease severity readings $1=1 \%$ to $10 \%, 2=11 \%$ to $25 \%, 3=26 \%$ to $50 \%, 4=51 \%$ to $75 \%$, and $5=$ $76 \%$ to $100 \%$ plant infection with spot anthracnose (Elsinoe corni) and Septoria leaf spot (Septoria cornicola). between pairs of means calculated by Statistical Analysis Systems (SAS). Similar data were obtained in 1999-2000; data were not taken in 1998.

Daughtrey, M.L., and A.K. Hagan. 2001. Dogwood diseases, pp 124-132. In Jones, R.K., and M.D. Benson. (Eds.). Diseases on Woody Ornamentals and Trees in Nurseries. APS Press, St. Paul, MN. 481 pp.

Hagan, A.K., and J. Mullen, 1995. Controlling powdery mildew on ornamentals. University of Alabama Circular ANR-407.

Hagan, A.K., C. Gilliam, G. Keever, and J.D. Williams. 1995. Reaction of dogwood selections to powdery mildew. Ornamental Research Report Series N o. 10. Alabama Agricultural Experiment Station. Auburn University, Auburn, AL. 50 pp.

Hagan, A.K., C. Gilliam, G. Keever, B. Williams, J.D. Hardin, and D.J. Eakes. 1997. Dogwood taxa differ in their susceptibility to powdery mildew and spot anthracnose, pp 35-37. In Ornamental Research Report Series No. 13. Alabama Agricultural Experiment Station. Auburn University, Auburn, AL.

H artman, J. 1998. Evaluation of fungicide application timing for dogwood powdery mildew, pp 24-25. In Proceedings of the Dogwood Workshop, 19 October 1998, Crossnore, NC. 
McRitchie, J.J. 1994. Powdery mildew of flowering dogwood. Florida Department of Agriculture Consumer Service Plant Pathology Circular N o. 368.

M mbaga, M.T. 1998. Effect of powdery mildew on growth of dogwood. Tenn. Nurserymen's Assoc. N ewsl. 8:16-17.

---.2000 . Winter survival and source of primary inoculum for powdery mildew of dogwood in Tenn. Plant Dis. 84:574- 579.

- - . 2002. Ascocarp formation and survival and primary inoculum production in Erysiphe (sect. M icrosphaera) pulchra in dogwood powdery mildew. Ann. Appl. Biol. 141:153-161.

Mmbaga, M.T., and H. Sheng. 2002. Evaluation of biorational products for powdery mildew management in Cornus florida. J. Environ. Hortic. 20:113-117.

Mmbaga, M.T., I.M. Eujayl, and H. Sheng. 2001. Resistance to powdery mildew in Cornus florida. Phytopathology 91:S64.

Ranney, T.G., L.F. Grand, and J.L. Knighten. 1994. Resistance of Cornus kousa taxa to dogwood anthracnose and powdery mildew. Proc. South. Nurserymen's Assoc. Res. Conf. 39:212-216.

Schlotzauer, S.D., and R.C. Littell. 1987. SAS System for Elementary Statistical Analysis. SAS Institute, Cary, NC. $416 \mathrm{pp}$.

Sinclair W.A., H. Lyon, and W.T. Johnson. 1987. Diseases of Trees and Shrubs. Cornell University Press, Ithaca, NY. $575 \mathrm{pp}$.

Wheeler, B.E.J. 1978. Powdery mildews of ornamentals, pp 441-445. In The Powdery Mildews. Spencer, D.M. (Ed.). Academic Press, London, UK/N ew York, NY.

Windham, M.T. 1996. Resistance to powdery mildew in flowering dogwood. Proc. South. Nurserymen's Assoc. Res. Conf. 41:195-199.
Acknowledgments. We thank Ms. Hongyan Sheng for her dedicated efforts in these studies. This work was partly funded by the USDA/CSREES Grant N 0.98-38814-6236 and by the Horticultural Research Institute.

\author{
${ }^{1 *} \mathrm{~N}$ ursery Crop Research Station \\ Tennessee State University \\ Institute for Agricultural and Environmental Research \\ N ursery Crop Research Station \\ 472 Cadillac Lane \\ M cM innville, TN 37110, U.S. \\ Plantpath@blomand.net \\ ${ }^{2}$ Tennessee State U niversity \\ Institute for Agricultural and Environmental Research \\ 3500 John A. Merritt Blvd. \\ Nashville, TN 37209-1561, U.S. \\ rsauve@ tnstate.edu \\ *Corresponding author.
}


Résumé. La résistance à trois maladies foliaires a été évaluée durant cinq années chez plusieurs espèces et cultivars de cournouillers. Des 51 évaluées, 20 étaient de Cornus kousa, $21 \mathrm{de}$ C. florida, $2 \mathrm{de}$ C. sericea, $2 \mathrm{de} \mathrm{C}$. mas, 1 de $C$. alternifolia et 5 d'hybrides interspécifiques de C. kousa $x$ C. florida. Le blanc des feuilles et l'anthracnose, causés par Erysiphe (sect. Microsphaera) pulchra et Elsinoe corni respectivement, étaient les mal adies les plus présentes et les plus sévères. Dix-huit cultivars de C. kousa, 1 de C. mas, 2 de C. sericea, $1 \mathrm{de} C$. alternifolia et 4 hybrides interspécifiques étaient hautement résistants au blanc des feuilles alors que 19 cultivars de C. florida étaient susceptibles, dont 2 modérément résistants. L'anthracnose était la seconde maladie en importance, mais son degré de sévérité était général ement faible. Trois cultivars de C. kousa, 10 de C. florida et $1 \mathrm{de} C$. mas étaient moyennement susceptibles à I'anthracnose. Les deux cultivars de C. sericea étaient hautement susceptible à la tache septorienne des feuilles (Septoria cornicola) et des infections majeures étaient observées tout au long de l'étude. La plupart des cultivars de C. florida étaient hautement susceptibles au blanc des feuilles alors que la plupart des cultivars de $C$. kousa étaient hautement résistants. Les résultats de cette étude suggèrent qu'une résistance multiple aux maladies chez le cornouiller pourrait être atteinte au moyen de croisements entre $C$. kousa et $C$. florida.

Zusammenfassung. In einer fünfjährigen Studie wurde der Krankheitswiderstand mehrerer Cornus spp. und Kultivare gegenüber 3 Blattkrankheiten getestet. Von den 51 Testteilnehmern waren $20 \mathrm{C}$. kouza, $21 \mathrm{C}$. florida, $2 \mathrm{C}$. sericea, $2 \mathrm{C}$. mas und $1 \mathrm{C}$. alternifolia und 5 interspezifische Hybriden aus $C$. kouza $\times C$. florida. Schimmel und Anthracnose, verursacht durch Erysiphe (sect. Microsphaera) pulchra und Elsinoe corni waren die vorherrschendsten und schwersten Erkrankungen. 18 Kultivare von C. kouza, einer von $C$. mas, zwei von $C$. sericea, einer von $C$. alternifolia und vier interspezifische $\mathrm{H}$ ybriden waren sehr resistent gegenüber Schimmel, während 19 C. florida Kultivare anfällig waren, davon allerdings zwei recht resistent. Anthracnose war die zweite bedeutende Krankheit, aber sie verlief nicht so schwerwiegend. Drei C. kouza Kultivare, 10 von $C$. florida und ein $C$. mas waren relativ anfällig für Anthracnose. Beide Kultivare von C. sericea waren sehr anfällig für Septoria-Blattfleckenkrankheit (Septoria cornicola) und während der Studie wurden schwere Infektionen beobachtet. Die meisten C. florida Kultivare waren sehr anfällig gegenüber Schimmel, während die meisten C. kouza Kultivare resistent waren. Die Ergebnisse dieser Studie ergeben, dass eine multiple Krankheitsresistenz in Hartriegel möglicherweise durch das Kreuzen von C. kouza und C. florida erreicht werden kann.

Resumen. Se evaluó la resistencia en varios especies y cultivares de Cornus a enfermedades ocasionadas por 3 patógenos foliares en un estudio de cinco años. De los 51 especimenes evaluados, 20 fueron de C. kousa, 21 de C. florida, 2 de C. sericea, 2 de C. mas, $1 \mathrm{deC}$. alternifolia y 5 híbridos ínter específicos de C. kousa x C. florida. El moho y la antracnosis causadas por Erysiphe (sect Microsphaera) pulchra y Elsinoe corni, respectivamente, fueron las enfermedades más severas. Dieciocho cultivares de C. kousa, $1 \mathrm{de}$ C. mas, 2 de C. sericea, 1 de C. artenifolia y 4 de híbridos ínter específicos, resultaron altamente resistentes al moho mientras 19 cultivares de C. florida fueron susceptibles, de los cuales 2 fueron moderadamente resistentes. La antracnosis fue la segunda enfermedad más prevaleciente, pero su severidad fue generalmente baja. Tres cultivares de C. kousa, $10 \mathrm{de} C$. florida y de C. mas fueron medianamente susceptibles a la antracnosis. Ambos cultivares de C. sericea resultaron altamente susceptibles a Septoria cornicola y se observaron fuertes infecciones a lo largo del estudio. La mayoría de los cultivares de $\mathrm{C}$. florida fueron al tamente susceptibles al moho mientras la mayoría de los cultivares de C. kousa fueron altamente resistentes. Los resultados del estudio sugieren que puede obtenerse resistencia a las enfermedades a través de cruzas con $\mathrm{C}$. kousa y $\mathrm{C}$. florida. 